Journal of Teacher Education for Sustainability, vol. 15, no. 1, pp. 73-83, 2013

\title{
COUNTRY'S COMPETITIVENESS AND SUSTAINABILITY IN THE CONTEXT OF THE HIGHER EDUCATION SYSTEM REFORMS
}

\author{
Elita Jermolajeva and Ludmila Aleksejeva \\ Daugavpils University, Latvia
}

\begin{abstract}
The accumulation of knowledge and its use have become important factors that promote economic development as they contribute to a country's competitiveness in the global economy. The basic significance of research is obtained by defining new approaches in the organisation, function and efficiency of the higher education system (HES) by emphasising its qualitative aspects. The aim of the article is to describe the influence of education reform on economic competitiveness, paying a special attention to analysing and evaluating international experiences from an interdisciplinary perspective, including economics, pedagogy, etc. Quantitative indicators are used to characterise specific features of the HES and the interaction of this system in the overall context of state development. Some aspects of the Latvian HES are also analysed. The economic activity of inhabitants often directly depends on their level of education. In order to reorganise the Latvian HES and increase its competitiveness and efficiency, thus ensuring quality and availability, the Latvian education system must define a middle-term (4-5 years) and long-term (10-15 years) development plan that is coordinated with national economic development.
\end{abstract}

Keywords: higher education system, sustainability, innovations, economic competitiveness, education reform

\section{Introduction}

Knowledge management, the coordinated and directed creation, accumulation, distribution and use of knowledge, is a complex process that represents one of the pillars of economic and social life covering the entire country and society. The functioning of the higher education system (HES) and the activities of individual higher educational institutions (HEIs) takes place in a very complex and not completely explicable context within an unpredictable changing social, political and economic environment. The interdisciplinary perspective that includes economic, pedagogic and social challenges, among others, significantly influences the choice of indicators and the results of efficiency measurements. Thus, if there is not a successful interaction of external and internal factors related to the HES and if the level of the HES's efficiency does not correspond to societal conditions and goals, in this case, the balanced development of the country, its competitiveness 
can be hindered. The HES and the outcomes it creates considerably influence the development of the country. On the other hand, contextual changes demand that a stronger attention be paid to the development of the HES. In this way, the improvement of higher education (HE) can be promoted with the goal of ensuring the sustainable development and competitiveness of the country. Consequently, the improvement of the HES must be realised in close relation to societal development, in general.

Changes in HE in Latvia and all over the world are connected to the general development of the state and society. The HES of Latvia has experienced fast and important changes during the last 20 years, evolving from a system that was largely elitist to its present form, which is widely accessible. This transition can be best evidenced by the more than doubling of the school population while the actual number of inhabitants significantly decreased. A study of the Latvian HES reveals that career choices, programme availability, facilities, equipment, etc. have increased substantially. Furthermore, an institutional base has been created, educational financing and the mechanisms to allocate resources are constantly being improved and a unified system of degrees and qualifications has been ensured.

But, at the same time, new challenges have arisen that are determined by international tendencies and by internal factors of the system. For instance, the funding of the HES is not regular and stable (especially following the global crisis and its consequences). Additionally, the negative character of demographic tendencies, the lack of innovative capacity and potential, and obstacles limiting knowledge transfer also negatively affect the HES. These factors, together with the globalisation process and the development of knowledge-based economy as well as internal structural imperfections of the system, create significant challenges for the sustainable development of the system in general.

\section{Conceptual framework and research methods}

Presently, European countries face new tendencies in the global environment that influence not only the way the HES operates, but effect the ultimate aims and objectives of this system. Scientific findings during the past 30 years have significantly changed many premises of education, making reform necessary in practically every education system (Carnoy, 1999; Fullan, 2005). Experts underline that contemporary HE in the Western Europe is undergoing its third wave of reforms in response to global tendencies such as massification, internationalisation and autonomy of the education services (Hargreaves \& Goodson, 2006). Many countries are reforming their education systems to provide their citizens with the knowledge and skills that enable them to engage actively in democratic societies and dynamic knowledge-based economies (Riley \& Torrance, 2004).

Individual experts also note the increasing mercantile tendency of educational services since the last decade of the 20th century (Apple, 2001). The mercantilisation of education values labour productivity, efficiency, responsibility and competitiveness, all of which are extensively included in the global education reforms. As a result, the standardisation and, as a consequence, responsibility and reporting were offered as means to increase education and education efficiency. Educational requirements of building democratic societies and enhancing economic competitiveness often contradict the changes introduced in these global education reforms (Sahlberg, 2004). 
The methodological approaches used to ensure the integral evaluation of the socioeconomic impacts of the HES is systemic, synergetic and qualimetric in nature include graphic, monographic and abstract-logical methods, institutional analysis, statistical and economic analysis. Quantitative indicators are used to characterise specific features of the HES. Calculations, methodology and definitions are provided by Eurostat. Educational statistics collected by the Ministry of Education and Science of the Republic of Latvia and the Global Competitiveness Report were also used.

To process and analyse research data, both the descriptive and the experimentalanalytical method were used. In the first case, descriptive methods were used to obtain a quantitative-qualitative description of the research object, its properties and condition. The experimental-analytical method was used to construct a model of functional and causational interactions that would provide an opportunity to develop appropriate policy alternatives.

\section{Findings and discussion}

Successful economies compete on the basis of high value, not only low cost. High value is best guaranteed by well-trained and educated personnel and flexible lifelong learning opportunities for all citizens (Hargreaves, 2003). Competitiveness is based on the determinants of the complex process of economic growth and development. When the competitiveness of economies is compared, a set of institutions, policies and structures is constructed using sub-indices that attempt to grasp the heterogeneity of different countries (Porter, Schwab, \& Lopez-Claros, 2005). Based on these commonly used determinants of economic competitiveness and various indicators of the knowledge economy, three core domains have been utilised to explain economic growth: education and training (human capital); use of information and communication technologies; innovations and technological adaptation (Porter et al., 2004).

Improving of the HES is a condition for successful development of the country as it ensures competitiveness. Figure 1 shows how education reform influences the factors that increase economic competitiveness (Sahlberg, 2004).

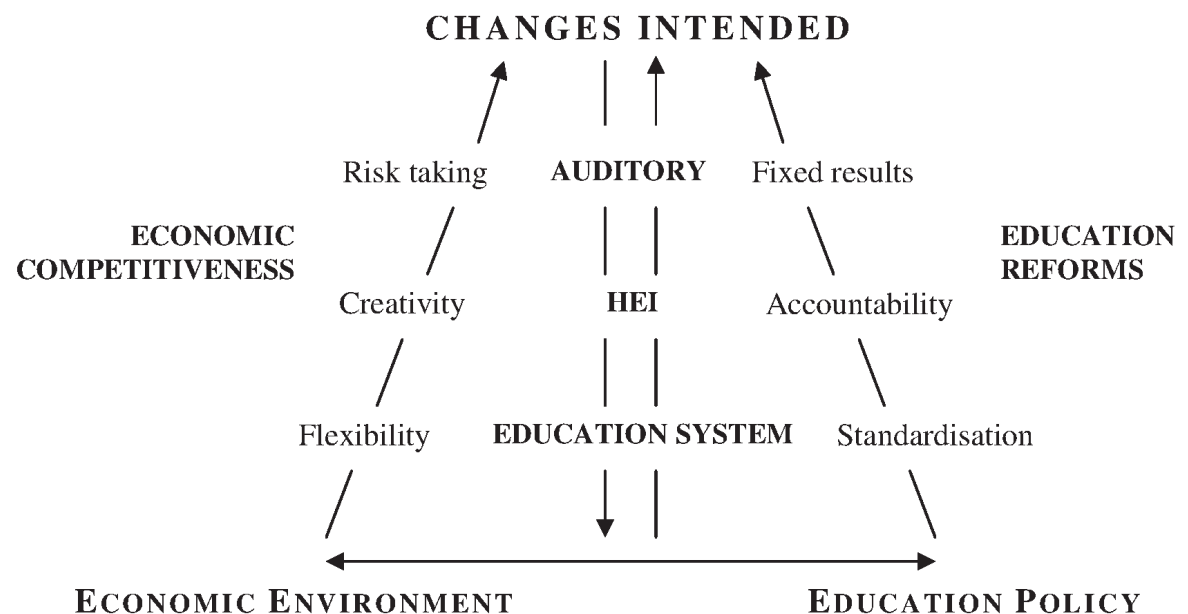

Figure 1. Factors of economic competitiveness and education reform (Sahlberg, 2004) 
From the macro point of view, the country's education system, including the HE subsystem, is linked in its external environment with three universal bonds: 1) societal education needs (HE demand) and the resources needed to satisfy these needs; 2) the possibilities of the education system (HE offers) and 3) the satisfaction of society's education needs (HE results) (Panina, 2010). The concept of the education system must include four basic components: values, goals, politics and elements for execution of decision making (mechanisms of need and financing or resource distribution) (Broks, Geske, Grīnfelds, Kangro, \& Valbis, 1998).

Thereby, if there is no successful interaction of external and internal factors put into practice in the HE system and if the efficiency level does not correspond to the existing state and overall societal goals, a balanced development and competitiveness of the country is hindered.

The goals of the education system are complex because they include both the preparation of people for labour market and the broader long-term objective - personal development. For instance, according to the data of the Flash Eurobarometer survey "Students and Higher Education Reform" (2009), 74\% of students indicated that the main objective of $\mathrm{HE}$ is to ensure employment (the total number of students questioned $\mathrm{n}=14$ 964, in Latvia $\mathrm{n}=525$ ). It should be noted that, in Latvia, the estimation of students was similar to the average European Union (EU) indicators, respectively, where $84 \%$ of HEI students stressed that the objective of HE is to ensure employment. In the same study, $56 \%$ indicated that an important aim of $\mathrm{HE}$ is to enhance personal development, also $49 \%$ noted the goal of $\mathrm{HE}$ is to educate an active citizen (Students and higher education reform, 2009).

Thus, assessing HE must be performed within a framework of a particular socioeconomic, historical, legal and political environment, taking into account not only the strategies of national economic development, but also global priorities of the system's development. Of course, the aims and objectives of education in different countries may mean different things; they may be different even for different groups of inhabitants of one country since there are differences in microeconomic tendencies among geographical areas, in the quality of the state institutes and technological development (Figure 2).

Beginning in the 1990s, considerable changes began to take place in HE systems of the EU which determined there was a need for reform in many countries. Some of the most important influences include globalisation, the constantly increasing value of knowledge as the main driver of growth and the rapid development of information and communication technologies. The accumulation and use of knowledge has become one of the most important factors affecting economic development as it increasingly determines a country's competitiveness in the global economy. In such conditions, its principal importance is acquired in the search for new approaches to the organisation, function and increased efficiency of the HEI, emphasising its qualitative aspects.

The most important reforms in the fields of the HE management and economy in Scandinavian and Baltic countries during the previous decade are shown in Table 1 (Progress in higher education reform across Europe, 2008). In Table 1, C indicates competitive institutions; $\mathrm{N}$ indicates negotiations-based institutions; $\mathrm{E}$ indicates evenly distributed across institutions. 


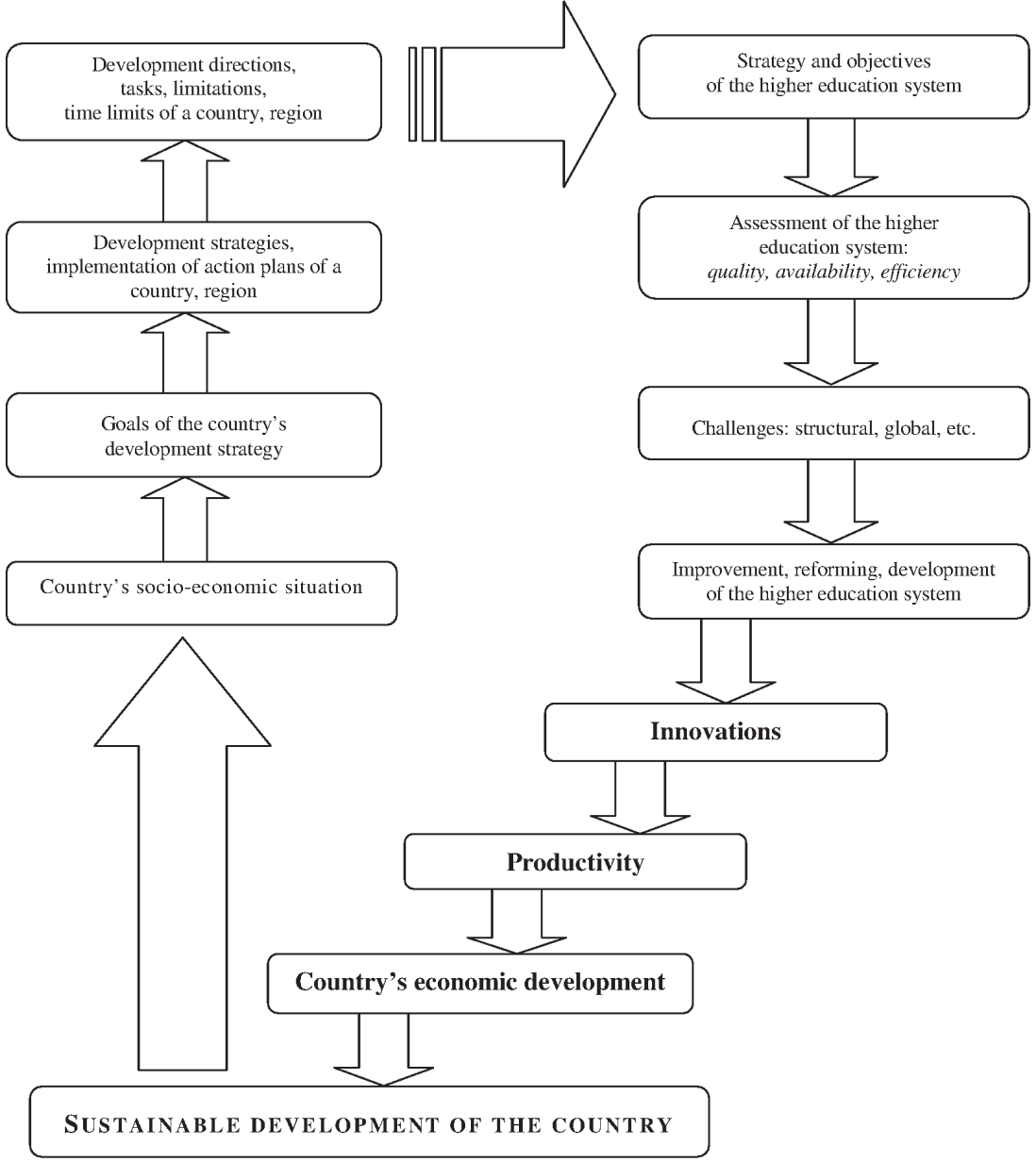

Figure 2. Interaction of the higher education system and sustainable development

Table 1. Targeted funding to address education-related goals: Areas where initiatives took place from 1995 to 2008

\begin{tabular}{ccccc}
\hline Country & $\begin{array}{c}\text { Initiatives on } \\
\text { area of Access }\end{array}$ & $\begin{array}{c}\text { Initiatives on } \\
\text { area of Efficiency }\end{array}$ & $\begin{array}{c}\text { Initiatives on } \\
\text { area of Quality }\end{array}$ & $\begin{array}{c}\text { Initiatives on } \\
\text { area of Mobility }\end{array}$ \\
\hline 1 & 2 & 3 & 4 & 5 \\
\hline Denmark & & $\begin{array}{l}\text { Completion and } \\
\text { time to degree } \\
(\mathrm{E})\end{array}$ & Excellence (C) & $\begin{array}{l}\text { Attracting inter- } \\
\text { national } \\
\text { students (E) }\end{array}$ \\
\hline Finland & $\begin{array}{l}\text { Special } \\
\text { programmes } \\
\text { (C) }\end{array}$ & Mergers (N) & $\begin{array}{l}\text { Quality of teaching } \\
(\mathrm{C})\end{array}$ \\
\hline Norway & & & \multicolumn{3}{l}{$\begin{array}{l}\text { Student } \\
\text { exchange (E) }\end{array}$} \\
\hline
\end{tabular}


Sequel to Table 1.

\begin{tabular}{|c|c|c|c|c|}
\hline 1 & 2 & 3 & 4 & 5 \\
\hline Sweden & $\begin{array}{l}\text { Capacity, low } \\
\text { SES, lifelong } \\
\text { learning, e-lear- } \\
\operatorname{ning}(\mathrm{C}, \mathrm{N})\end{array}$ & $\operatorname{Mergers}(\mathrm{C}, \mathrm{N})$ & $\begin{array}{l}\text { Curriculum inno- } \\
\text { vation, strategic } \\
\text { programmes } \\
(\mathrm{C}, \mathrm{N})\end{array}$ & $\begin{array}{l}\text { Student } \\
\text { exchange }(\mathrm{C}, \mathrm{N})\end{array}$ \\
\hline Estonia & $\begin{array}{l}\text { Social economic } \\
\text { status partici- } \\
\text { pation }(\mathrm{N}, \mathrm{C})\end{array}$ & & $\begin{array}{l}\text { Curriculum inno- } \\
\text { vations and stra- } \\
\text { tegic programmes } \\
(\mathrm{N}, \mathrm{C})\end{array}$ & \\
\hline Latvia & $\begin{array}{l}\text { Enhance } \\
\text { capacity }(\mathrm{N})\end{array}$ & & & $\begin{array}{l}\text { Sending abroad } \\
(\mathrm{N})\end{array}$ \\
\hline Lithuania & & & & $\begin{array}{l}\text { Sending abroad } \\
(\mathrm{N})\end{array}$ \\
\hline
\end{tabular}

One of the most important driving forces of reforms in modern times is the improvement of the HES. This HE component is related to several aspects. Firstly, it is linked with the constantly increasing diversity of HEI resources and, consequently, the number of participants involved as well as the diversity of their demands. Secondly, it is related to the global competition among education systems. Thirdly, the global recession has created financial difficulties for students to pay for their studies and for governments and businesses to finance the work of HEI.

A country's ranking in the global competitiveness index represents an important source of information about the economic situation of a country as it uses a unified system to reveal the strengths and weaknesses of every country in specific fields of competitiveness. One of the determining factors of competitiveness is the quality of HE. The most recent available data (2011) show that among 131 countries the competitiveness of Latvia's HE ranks 35th (Estonia - 22nd place, Lithuania - 25th place). The analysis of the pillars and factors determining the competitiveness in Latvia when compared to other Baltic and Scandinavian countries (Figure 3) is carried out within the global competitiveness monitoring (Schwab, 2010).

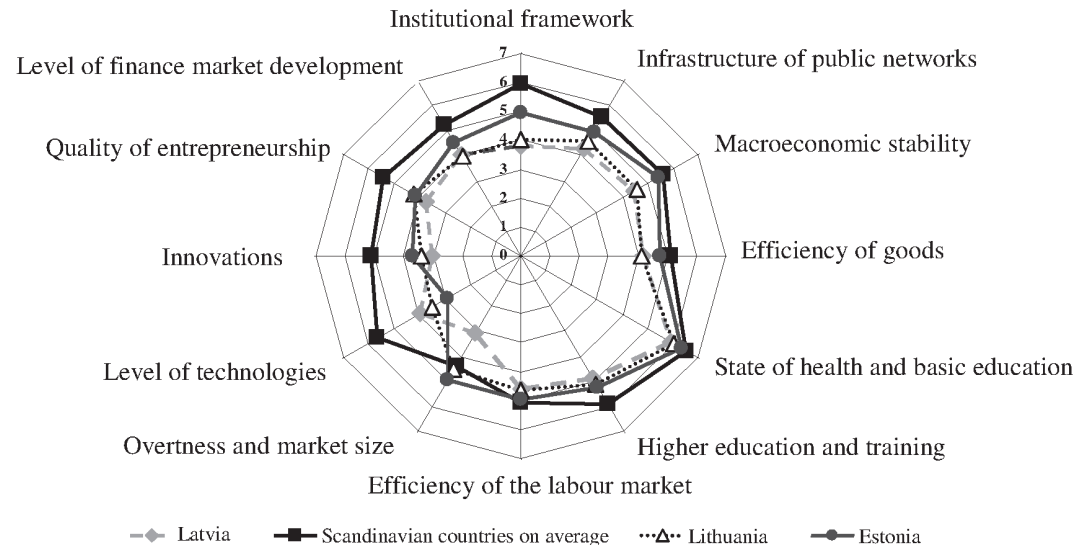

Figure 3. Comparison of the indicators of the Global Competitiveness Index among countries in 2010-2011 (Schwab, 2010) 
Latvia lags behind the Scandinavian countries both by the rating of the $\mathrm{HE}$ and by other indicators related to the education: innovations, level of technologies and efficiency of the labour market. The innovation index in Finland is 5.56, in Sweden - 5.45, in the United States of America - 5.65, but in Latvia - only 3.02. Latvia has the lowest ranking among its neighbouring countries. Innovations and qualitative aspects related to the development of entrepreneurship are determining factors in economic development and the development of a knowledge-based economy. Latvia has a very low rating both among world countries and among our neighbour countries. The low level of cluster development (113th place), the low quality of research institutions (66th place) as well as the low cooperation of HEIs and branches in the field of research (86th place) deserve particular attention (Table 2).

Table 2. Indices of competitiveness, higher education quality, innovation and knowledge-based economy in different countries

\begin{tabular}{lcccc}
\hline Country & $\begin{array}{c}\text { Global competiti- } \\
\text { veness index (GCI) } \\
\mathbf{2 0 1 0 - 2 0 1 1}\end{array}$ & $\begin{array}{c}\text { Higher education } \\
\text { quality index } \\
\mathbf{2 0 1 0 - 2 0 1 1}\end{array}$ & $\begin{array}{c}\text { Knowledge-based } \\
\text { economy index } \\
\text { (KEI) } 2009\end{array}$ & $\begin{array}{c}\text { Global innovation } \\
\text { index (GII) } \\
\text { 2009-2010 }\end{array}$ \\
\hline Norway & 14 & 12 & 5 & 10 \\
\hline Sweden & 2 & 2 & 2 & 2 \\
\hline Finland & 7 & 1 & 3 & 6 \\
\hline Denmark & 9 & 3 & 1 & 5 \\
\hline Estonia & 33 & 22 & 21 & 39 \\
\hline Lithuania & 47 & 25 & 31 & 44 \\
\hline Latvia & 70 & 35 & 32 & \\
\hline
\end{tabular}

The same is true with innovation and knowledge-based economy indices. The World Bank ranks the knowledge-based economy (KEI) of Latvia 32nd, which is the lowest indicator among the Baltic countries. However, it is important to note that northern European countries lead the field of knowledge-based economy development. Also, Latvia is 44th in the innovation index (GII), while Lithuania and Estonia are 39th and 29 th, respectively. A higher level of education promotes fundamental innovations as well as the adoption and imitation of global high-tech practices. Lamentably, Latvia does not appear to use these possibilities (Table 2).

Countries like Denmark, Sweden, Norway and Finland are consistently reforming their HES, constantly improving the system in general and in its components. The HES of these countries have gradually ensured the competitiveness and sustainable development of the country, and this is confirmed by their leading positions in the global competitiveness index, global innovation index and other indicators. The reforms of the previous decade include associations, integration, structural cooperation and the creation of strategic alliances with Norway, Denmark, Finland and other European countries.

Paying a more detailed attention to Finland's HE system and examining its correlations with the processes of national economy, it is possible to reach some conclusions. Firstly, Findland's economic policy is based on the integration of different branches (Aho, Pitkänen, \& Sahlberg, 2006). The mid-term policy anticipates the integration of the education and vocational training systems, involvement of the private sector and industry participation in evaluating the education system's quality, in formulating require- 
ments and in monitoring process (Sahlberg, 2006). Secondly, the strategic framework of education system development and reformation has a long-term character. Thirdly, the influence of the state administration and institutions has a significant role in the policy of the HE and in the implementation of education and economic reforms (Sahlberg, 2009). Efficient state administration and the high level of development of public institutions play a significant role in the creation and execution of the policy of society's subsystems as well as in the implementation of the changes planned. Fourthly, well-educated human resources and their expanded involvement in continuous education guarantee the improvement of human capital that is necessary to ensure HE services and economic growth. One of the main qualities of the Finnish education and economic systems is their flexibility.

The most important changes in Findland's HE took place in the early 1990s when the majority of state regulatory functions were cancelled but educational opportunities and directions expanded (Routti \& Yla-Anttila, 2005; Aho et al., 2006). In the same way, the regulatory influence of the state in the private sector was diminished, while more flexible standards were introduced. All of that ensured the development of network interaction between the region, state and business in HEI. The integrated policy and long-term state strategic planning ensured the Finnish HE system took a leading position in the whole world as well as consolidated the country's competitiveness and successful development of the private sector. A constant dialogue between state and private HEIs permitted a mutual understanding about the anticipated results and factors of society and the development of a knowledge economy. As a result, education institutions, too, were more actively involved in the introduction of experiments by using creative technologies, developing business skills and promoting positive student attitudes towards work. Strong integrated policy frameworks and long-term strategic visions have enhanced sustainable leadership in education and private sector development (Sahlberg, 2006, 2007).

World practice shows that the increasing distribution of $\mathrm{HE}$ is strongly related to work productivity and economic competitiveness (Figure 4). Also, in this aspect, the tendency in Baltic and Scandinavian countries is similar.

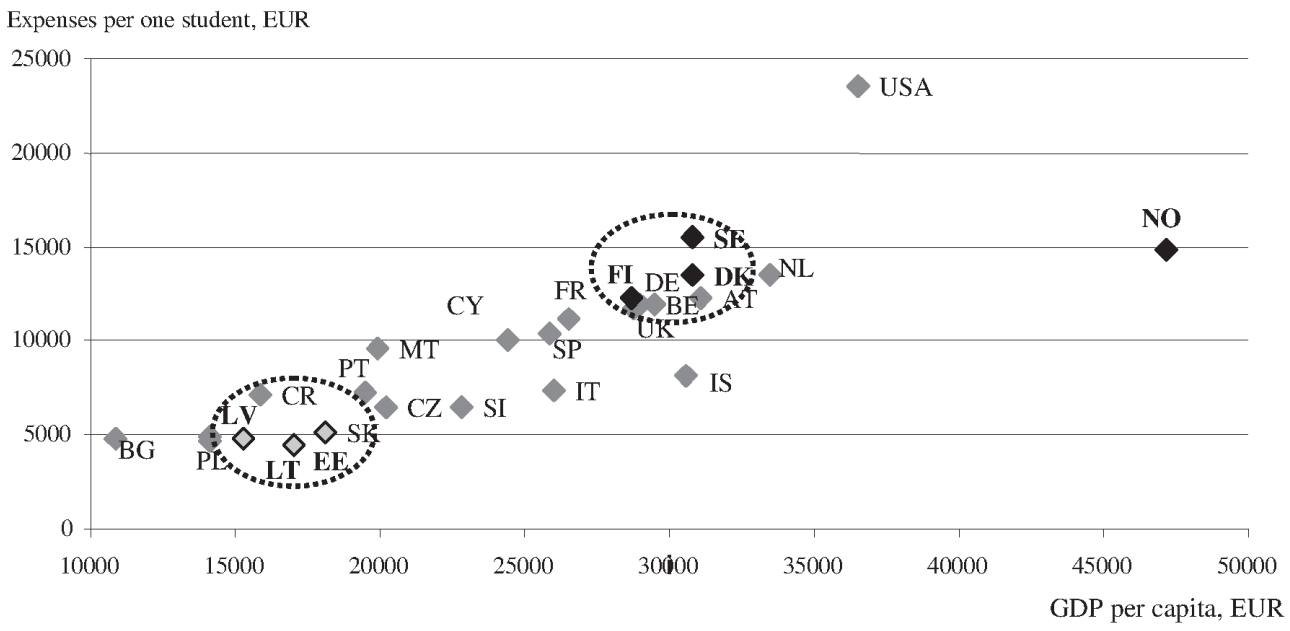

Figure 4. Expenditure per one student compared to GDP per capita in the EU countries in 2008, EUR 
Researchers stress that one of the contributing factors for regional development could be a partnership between HEI and regional businesses that more efficiently integrates HEI in the regional context (Eglitis \& Panina, 2010; Jermolajeva, Eglitis, Panina, \& Ostrovska 2010). Integration of HEIs and the business environment is the usual practice in developed countries (Goddard, 2006; Organisation for Economic Co-operation and Development [OECD], 2007; Huggins Jones, \& Upton, 2008). HEIs are one of the important factors promoting regional development (Pawlowski, 2009).

The development of the world's economically most powerful countries shows that these countries have opened their economies to innovative solutions decades ago. Despite the comparatively high indicators of HE achievements, the HE systems in the Scandinavian countries are still in the reformation process. The same is true about the Baltic countries where the HE systems have undergone intensive reforms since the 1990s and whose performance is not yet outstanding. The Baltic countries do, however, continue to search for better mechanisms to manage and govern the educational system as well as improved directions for general system development. When analysing interconnections, one of the most important conclusions is the following: the economic activity of inhabitants and their involvement in the processes taking place in the country directly depends on the person's level of education.

HE provides opportunities and benefits not only for HEI graduates, but there are 'external benefits', too, that are related to progress in science, innovative potential, economic growth and cultural development. Society is directly interested in how HES contributes to the economic and social needs of society and ensures international competitiveness.

On the other hand, macroeconomic policy may provide a considerable impulse for the development of $\mathrm{HE}$ (demand-driven $\mathrm{HE}$ ) in different ways. For instance, when supporting the business sector and promoting the stability of the labour market, it is also possible to achieve the development of the HES. Of course, it is a long-term activity, but the opposite is also true: a highly developed HES with promotes macroeconomic growth, providing balanced regional development and increased international competitiveness.

\section{Conclusion}

The economic activity of inhabitants and their involvement in socio-economic life is directly dependent on the person's level of education. The HE system and the outcomes it creates have a clear impact on the development of the country. The improvement of the HES is a condition for the successful development of the country and its competitiveness. Target-oriented reforms in the HES depend on a positive synergy between the education structure and the participation of all stakeholders. This positive synergy is important for both the education system itself and the economic growth of the country.

The experiences of economically advanced countries show that they opened their economies to innovative solutions several decades ago. For some countries, economic globalisation and rapid technological development have created a unique opportunity for accelerated development. However, for other countries, there are threats of stagnation or even recession. Countries such as Denmark, Sweden, Norway and Finland are consistently conducting reforms of their HES, constantly improving the efficiency of their educational system, in general as well as its particular elements. During the previous 
decade, the most important changes were directed towards improving the performance of HE. As a result, the structure of resource investment indicators has been improved, activities of system reorganisation have been carried out and student mobility is significantly expanding. The system and performance indicators of HE have also been improved with the goal of motivating HEIs towards self-improvement. The HES of these countries has gradually ensured competitiveness and sustainable development, as revealed by their leading positions in the Global Competitiveness Index, Knowledge Economy Index and the Global Innovation Index (2011), among others.

In Latvia, it is necessary for the economic policy to create conditions that contribute to the competitiveness of Latvia and foster the development of a knowledge-based economy with a strong export sector, including high technology with high added value that will play a leading role in furthering economic development.

To accomplish the reorganisation of the HES needed to increase the competitiveness and efficiency of HE, the Latvian education system must create a middle-term (4-5 years) and long-term (10-15 years) development concept that would be coordinated with the corresponding planning and vision of Latvian national economy.

\section{References:}

Aho, E., Pitkänen, K., \& Sahlberg, P. (2006). Policy development and reform principles in Finland since 1968. Retrieved March 13, 2011, from http://www.see-educoop.net/ education_in/pdf/workshop/tesee/dokumenti/education-in-finland-2006.pdf

Apple, M. (2001). Educating the "right" way. Markets, standards, god and inequality. New York: Routledge Falmer.

Broks, A., Geske, A., Grīnfelds, A., Kangro, A., \& Valbis J. (1998). Izglìtības indikatoru sistēmas [Systems of education indicators]. Rīga: Mācību Grāmata.

Carnoy, M. (1999). Globalization and educational reform. What planners need to know? Paris: UNESCO and IIEP.

Eglitis, J., \& Panina, L. (2010). Tertiary education in Latvia today and tomorrow. Perspectives of Innovations, Economics \& Business, 4(1), 93-97.

Fullan, M. (2005). Leadership and sustainability: System thinkers in action. Thousand Oaks, CA: Corwin Press.

Goddard, J. (2006). The role of HEIs in linking innovation and territorial development. Retrieved May 17, 2008, from http://www.eua.be/eua/jsp/en/upload/PLII.1_ Goddard. 1161612067455.pdf

Global Innovation Index. (2011). Retrieved April 28, 2011, from http://www. global innovationindex org/gii/main/reports/2009-10/FullReport_09-10.pdf

Hargreaves, A. (2003). Teaching in the knowledge society: Education in the age of insecurity. New York: Teacher College Press.

Hargreaves, A., \& Goodson, I. (2006). Educational change over time? The sustainability and non-sustainability of three decades of secondary school change and continuity. Educational Administration Quarterly, 42(1), 3-41.

OECD (Organisation for Economic Co-operation and Development). (2007). Higher education and regions: Globally competitive, locally engaged. Paris: OECD Publishing.

Huggins, R., Jones, M., \& Upton, S. (2008). Universities as drivers of knowledge-based regional development: A tripple helix analyses of Wales. International Journal of Innovation and Regional Development, 1(1), 24-47. 
Jermolajeva, E., Eglitis, J., Panina, L., \& Ostrovska, I. (2010). Challenges and sollutions in promoting the cooperation of higher education and business. International Business: Innovations, Psychology, Economics. Research papers, 1(1), 9-23.

Knowledge Economy Index. (2011). Retrieved April 28, 2011, from http://info. worldbank.org/ etools/kam2/KAM_page5.asp

Paṇina, L. (2010). Augstākās izglītības efektivitātes indikatori: metodoloǵiskie aspekti un Eiropas valstu pieredze [Indikators of higher education effectiveness: Methodological aspects and the experience of European countries]. Daugavpils Universitātes 51. starptautiskās zinātniskās konferences materiāli [Proceedings of the 51th International Scientific Conference of Daugavpils University], 2, 185-196.

Pawlowski, K. (2009). The "Fourth generation university" as a creator of the local and regional development. Higher Education in Europe, 34(1), 51-64. DOI: 10.1080/ 03797720902747017.

Porter, M. E., Schwab, K., \& Lopez-Claros, A. (2005). The global competitiveness report 2005-2006: Policies underpinning rising prosperity. Retrieved May 12, 2010, from http://www.weforum.org/issues/global-competitiveness

Progress in higher education reform across Europe. (2008). Volume 1: Executive summary and main report. Retrieved May 12, 2010, from http://ec.europa.eu/ education/higher-education/doc/funding/vol1_en.pdf

Riley, K., \& Torrance, H. (2003). Big change question: As national policy-makers seek to find solutions to national education issues, do international comparisons such as TIMSS and PISA create a wider understanding, or do they serve to promote the orthodoxies of international agencies? Journal of Educational Change, 4(4), 419-425.

Routti, J., \& Ylä-Anttila, P. (2005). Finland as a knowledge economy. Elements of success and lessons learned. Washington, DC: World Bank.

Sahlberg, P. (2004). Teaching and globalization. International Research Journal of Managing Global Transitions, 2(1), 65-83.

Sahlberg, P. (2006). Education reform for raising economic competitiveness. Journal of Educational Change. 7, 259-287. Retrieved September 20, 2010, from http:// www.pasisahlberg.com/downloads/Education \%20reform $\% 20$ for $\% 20$ economic $\%$ 20competitiveness \%20JEC.pdf

Sahlberg, P. (2007). Education policies for raising student learning: The Finnish approach. Journal of Education Policy, 22(2), 147-171.

Sahlberg, P. (2009). Educational change in Finland. Second international handbook of educational change. New York: Springer.

Students and Higher Education Reform. (2009). Analytical Report European Commission, Flash Eurobarometer No 260. Retrieved September 7, 2011, from http://ec. europa.eu/public_opinion/flash/fl_260_en.pdf

Schwab, K. (2010). The Global Competitiveness Report 2010-2011. Retrieved March 17, 2011, from http://www3.weforum.org/docs/WEF_GlobalCompetitiveness Report_2010-11.pdf

\section{Correspondence:}

Elita Jermolajeva, Doctor of Economics, Associated Professor, Daugavpils University, MeRSA (Member of Regional Studies Association), 1 Parādes Street, 331, Daugavpils, LV-5401, Latvia. Email: elita.jermolajeva@du.lv 